\title{
Nanocomposite materials used for ground heat exchanger pipes
}

\author{
Jean-Sébastien \\ Gosselin
}

\author{
Jasmin \\ Raymond
}

\author{
Stéphane \\ Gonthier
}

\author{
Mathieu \\ Brousseau
}

\section{Jean-François Lavoie}

\begin{abstract}
This study compares the performance of single U-pipe, double U-pipe, and coaxial ground heat exchangers (GHE) equipped with standard HDPE and thermally enhanced (TE) pipes. Sizing calculations and 10-year hourly simulations were carried out with the GLHEPro software using as input a synthetic thermal load profile of a reference, heating-dominated, medium office building located in the U.S. climate zone 5B enclosing Colorado. Energy consumption by the ground heat and ground loop pumps were then calculated from the simulated outputs. Finally, a life-cycle cost analysis was performed to compare the total costs (construction and operation) net present value of the GHEs equipped with TE pipes with those equipped with standard HDPE pipes. Results showed that the double U-pipe with thermally enhanced pipes was the best option for the conditions considered in the study. Depending on the configuration, the use of TE pipes instead of standard HDPE pipes allowed a reduction of the GHE length between 9 and $14.8 \%$ and a reduction of the construction cost between 3.3 and 8.6\%. For each configuration tested, the operation costs were similar between the GHEs equipped with HDPE and TE pipes. This study demonstrates that GHEs equipped with TE pipes can be a financially viable and environmentally beneficial solution, especially if secondary benefits are factored in such as saved footprints on available real estate.
\end{abstract}

\section{INTRODUCTION}

Ground-coupled heat pumps are energy efficient and environmentally friendly systems for heating and cooling buildings but are expensive to install. The ground heat exchanger (GHE) is the most expensive component of the system. This is particularly true for vertical GHEs installed in boreholes that tend to be more expensive than horizontal installations in trenches. Technological innovations, such as space clips holding pipes separately and thermally enhanced grout (Allan and Kavanaugh, 1999) can be used to reduce the borehole thermal resistance, which translates in GHE fields with shorter and/or fewer boreholes that are cheaper to install. The thermal conductivity of the pipes is also a factor affecting the borehole thermal resistance. Typically, GHEs are built using high-density polyethylene (HDPE) pipes, which are actually thermal insulators that increase the thermal resistance of boreholes.

In recent years, significant research efforts have been made to develop thermally enhanced (TE) polymers with inorganic nanomaterial fillers due to potential applications in the automotive, aerospace, constructions, and electronic industries. These applications are for example heat sinks in electronic devices, tubing for heat exchangers, enclosures for electronic appliances, casing for small motors, and heat exchangers used in corrosive environments (Gupta et al., 2009). In the geothermal sector, commercial pipes made with HDPE resin loaded with a carbon filler have shown an increase of thermal conductivity by about $75 \%$ compared to traditional grades of HDPE used for pipes (Versaprofiles, 2014). Design calculations indicated that these thermally enhanced pipes can reduce the thermal resistance of vertical GHEs by 10 to $50 \%$, depending on the proposed configuration using U-shaped or concentric pipes. This allows a 5 to $25 \%$ reduction of the total drilling length required to fulfill the building heating and cooling needs (Raymond and Léger, 2011; Raymond et al., 2011, 2015).

While the aforementioned research showed the potential reduction of the boreholes thermal resistance and GHEs length, none have evaluated how much the use of TE pipes, which have currently a higher trade cost than conventional HDPE pipes, would impact the construction and operation costs of GHEs. The objective of this study was to evaluate the economic benefits of TE pipes by comparing sizing calculations and 10-year hourly simulations for various configurations of GHEs (single U-pipe,

Jean-Sébastien Gosselin (jean-sebastien.gosselin@ete.inrs.ca) is a postdoctoral student and Jasmin Raymond is a professor in geothermal energy at INRS-ETE. Mathieu Brousseau and Jean-François Lavoie are engineers working at Versaprofiles that produce thermally enhanced pipes for ground-coupled heat pump systems. Stéphane Gonthier is the president of Versaprofiles 
double U-pipe, and coaxial) equipped with standard HDPE and TE geothermal pipes. In addition to the construction costs, an energy analysis was carried out and allowed to take into account the operation costs of the ground heat and loop circulation pumps linked to the GHE field.

\section{METHODOLOGY}

Sizing calculations were carried out with the GLHEPro software (Ground Loop Heat Exchanger Professional; Spitler, 2000; Spitler et al., 2016), using as input, a synthetic thermal load profile of a reference, heating-dominated, medium office building located in the U.S. climate zone 5B enclosing Colorado (see Figure 1). Three different configurations of GHEs were considered: single U-pipe, double U-pipe, and coaxial (see Figure 2). For each configuration, a GHE was designed with standard HDPE and TE pipes using the full building loads. The operating conditions of each of the GHEs thus designed were then simulated on an hourly basis with GLHEPro over a 10-year period. The simulation outputs were then used to compute the electrical energy consumption of the ground heat pumps (GHP) and of the ground loop pumps (GLP) used to circulate the fluid. The results obtained from the sizing calculations and energy consumption analysis were then used to perform a life-cycle cost analysis to compare the economic performance of the GHEs equipped with TE pipes with those equipped with standard HDPE pipes.

\section{GHE Design Specifications}

Building Load Profile. Figure 1 presents the thermal load profile of a reference $4982 \mathrm{~m}^{2}\left(53628 \mathrm{ft}^{2}\right), 15 \mathrm{zones}^{2}$ three-story office building located in the U.S. climate zone 5B. This synthetic dataset was created by the Office of Energy Efficiency \& Renewable Energy (EERE) with the EnergyPlus simulation software (Crawley et al., 2000) using a typical meteorological year at the Denver location. Heating demand is higher during the months of October to April and from May to June for cooling. Heating is dominant, with annual heating and cooling requirements of, respectively, $106.9 \mathrm{MW} \cdot \mathrm{h} / \mathrm{yr}$ and $66.1 \mathrm{MW} \cdot \mathrm{h} / \mathrm{yr}$, corresponding to a heating on cooling ratio of 1.6 .

Sizing calculation of the GHEs was carried out using monthly total and peak loads that were calculated from the hourly load profile using the Peak Load Analysis Tool distributed with GLHEPro. The maximum heating peak load occurred in January with a value estimated at $249.1 \mathrm{~kW}(850.0 \mathrm{kBtu} / \mathrm{h})$ and a duration of $3 \mathrm{~h}$, while the maximum cooling peak load occurred in June with an estimated value of $104.8 \mathrm{~kW}(357.6 \mathrm{kBtu} / \mathrm{h})$ and a duration of $7 \mathrm{~h}$.

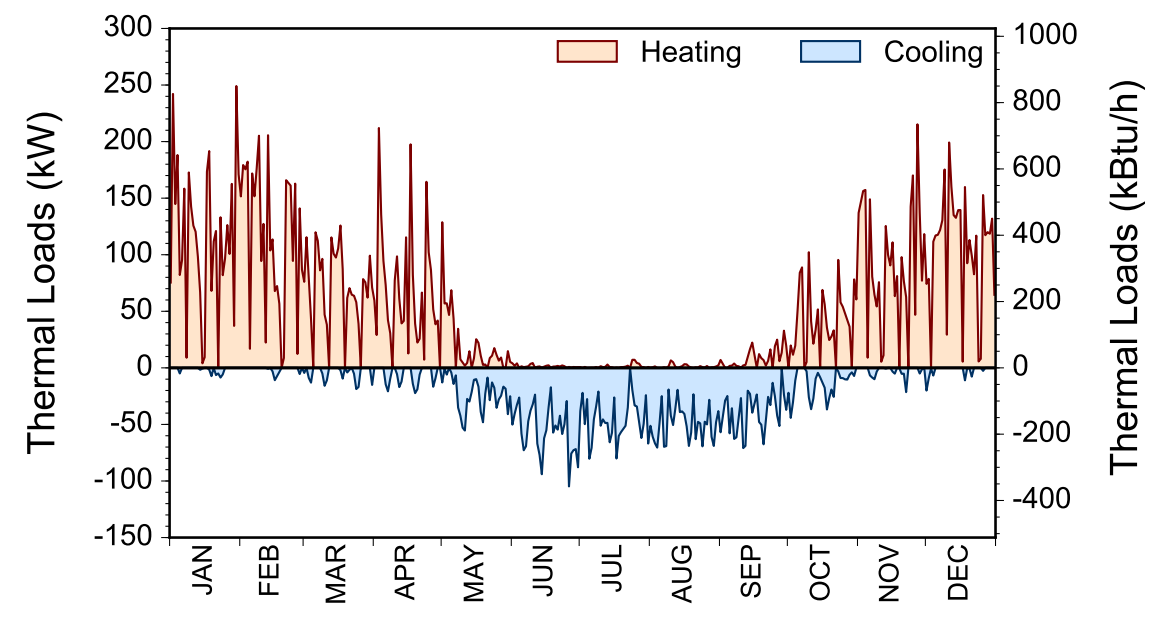

Figure 1: Typical one-year building load profile of a reference $4982 \mathrm{~m}^{2}\left(53628 \mathrm{ft}^{2}\right), 15$ zones, three-story office building located in the U.S. climate zone $5 \mathrm{~B}$ enclosing Colorado.

GHE Materials and Configurations. For each configuration considered (Figure 2), sizing calculations and 10-year hourly simulations were carried out for two different designs: one using thermally enhanced pipes and another using standard HDPE pipes. The boreholes were arranged in a rectangular grid pattern with a separation distance of $6 \mathrm{~m}(19.7 \mathrm{ft})(\mathrm{see}$ Section 2.1 .2$)$ to reduce the thermal interference between individual bores (ASHRAE, 2011). The GHE design strategy consisted in adding or removing boreholes from the borefield until the borehole depth was within $150 \pm 10 \mathrm{~m}(492 \pm 33 \mathrm{ft})$.

All boreholes were assumed to have a diameter of $152.4 \mathrm{~mm}(6 \mathrm{in})$ and to be filled with a thermally enhance grouting with an average thermal conductivity of $1.9 \mathrm{~W} / \mathrm{m} \cdot \mathrm{K}\left(1.10 \mathrm{Btu} / \mathrm{h} \cdot \mathrm{ft} \cdot{ }^{\circ} \mathrm{F}\right)$. Thermal conductivity of the subsurface was set to a 


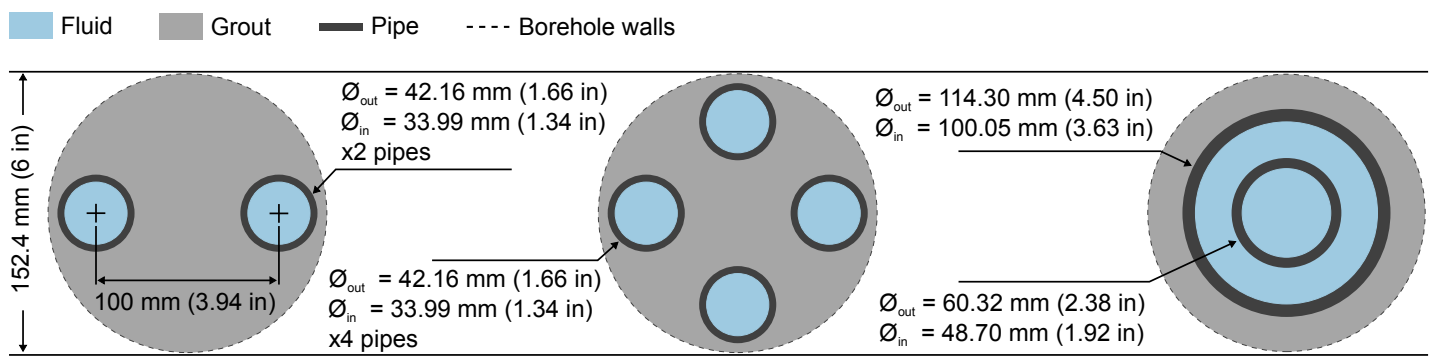

(a) Single U-Pipe

(b) Double U-Pipe

(c) Coaxial

Figure 2: Scale drawing showing the pipe and the drilling dimensions of the three different ground heat exchanger configurations for which sizing calculations and hourly simulations were carried out in this study using, alternately, standard HDPE and thermally enhanced pipes.

constant value of $3.0 \mathrm{~W} / \mathrm{m} \cdot \mathrm{K}\left(1.74 \mathrm{Btu} / \mathrm{h} \cdot \mathrm{ft} \cdot{ }^{\circ} \mathrm{F}\right)$, which is a value that is representative of a granite, limestone, or sandstone bedrock material (ASHRAE, 2011). The volumetric heat capacity for the subsurface and grouting were set, respectively, to $2343 \mathrm{~kJ} /{ }^{\circ} \mathrm{C} \cdot \mathrm{m}^{3}\left(34.9 \mathrm{Btu} / \mathrm{ft}^{3} \cdot{ }^{\circ} \mathrm{F}\right)$ and $3901 \mathrm{~kJ} /{ }^{\circ} \mathrm{C} \cdot \mathrm{m}^{3}\left(58.2 \mathrm{Btu} / \mathrm{ft}^{3} \cdot{ }^{\circ} \mathrm{F}\right)$.

The nominal diameter of the pipes used for the single and double U-pipe configuration was $31.8 \mathrm{~mm}(1.25 \mathrm{in})$ and the standard dimension ratio (SDR) was 11 (Figures 2a and 2b). Space clips, attached every $3 \mathrm{~m}$ (10 ft) along the U-pipe, were assumed to separate the pipes from each other with a center-to-center distance of $100 \mathrm{~mm}$ (3.94 in). This allowed to reduce the borehole thermal resistance and the thermal short-circuiting between the cold and hot leg of the U-pipes, consequently increasing the performance of the GHEs (Hellström, 1991; Claesson and Hellström, 2011). The thermal conductivity of standard HDPE and TE pipes were set, respectively, to a value of $0.4 \mathrm{~W} / \mathrm{m} \cdot \mathrm{K}\left(0.23 \mathrm{Btu} / \mathrm{h} \cdot \mathrm{ft} \cdot{ }^{\circ} \mathrm{F}\right)$ and $0.7 \mathrm{~W} / \mathrm{m} \cdot \mathrm{K}\left(0.41 \mathrm{Btu} / \mathrm{h} \cdot \mathrm{ft} \cdot{ }^{\circ} \mathrm{F}\right)$, as reported in Raymond et al. (2015), while the volumetric heat capacity was set to a value of $1543 \mathrm{~kJ} /{ }^{\circ} \mathrm{C} \cdot \mathrm{m}^{3}\left(23.0 \mathrm{Btu} / \mathrm{ft}^{3} \cdot{ }^{\circ} \mathrm{F}\right)$ for both types of pipe material.

The alternative coaxial design considered in this study (Figure 2c) involved the use of two pipes installed in each other. The size of the coaxial configuration was based on Raymond et al. (2015). The inner pipe had a nominal diameter of $50.8 \mathrm{~mm}$ ( $2 \mathrm{in}$ ) and a SDR of 11, while the outer pipe had a nominal diameter of $101.6 \mathrm{~mm}(4 \mathrm{in})$ and a SDR of 17. Two different cases for the coaxial were considered: one with an outer pipe made of HDPE and another with a TE pipe. In both cases, standard HDPE material was used for the inner pipe in order to minimize the thermal short-circuiting effect between the annulus and the inner pipe. The thermal conductivity and volumetric heat capacity for the HDPE and TE pipes were kept identical to the values given above for the U-pipe configurations.

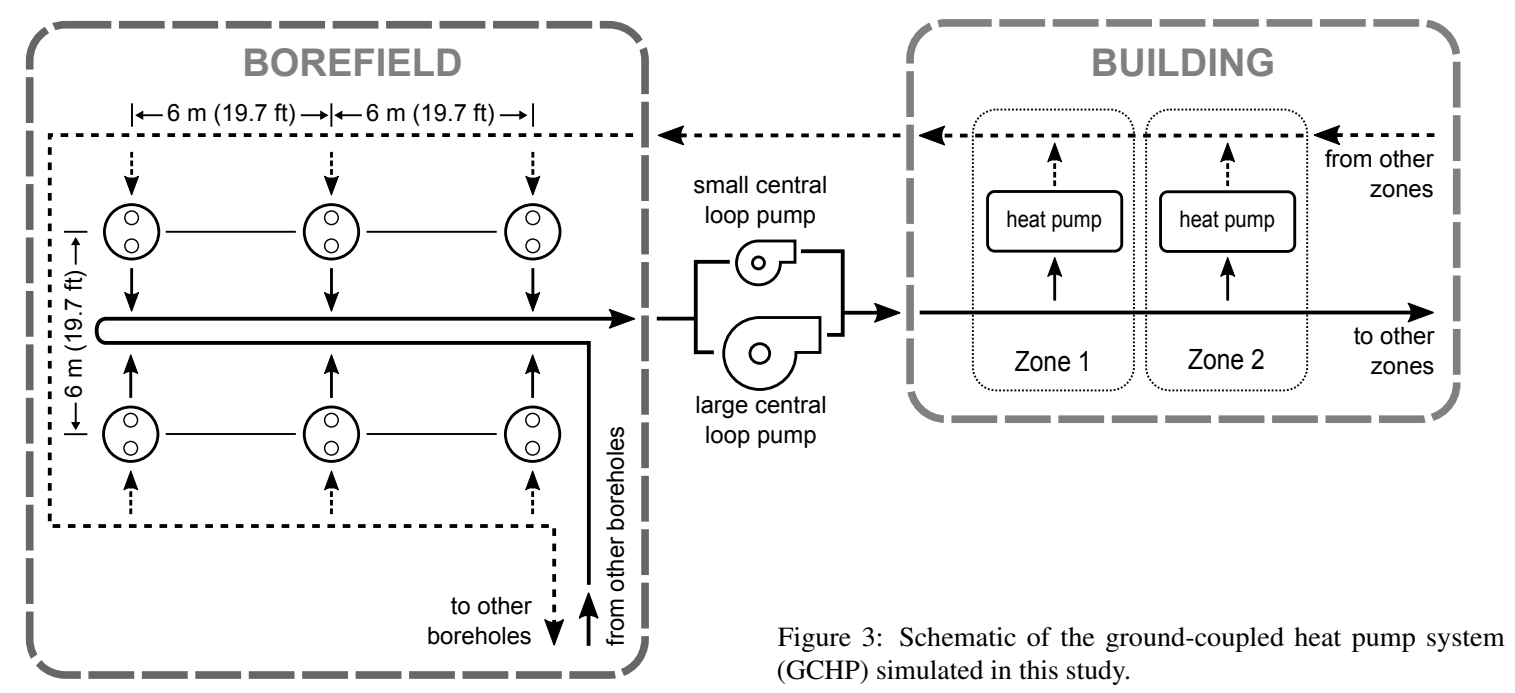


Ground Heat Pumps Selection. Fifteen commercially available ground heat pumps (ClimateMaster, 2016) with a nominal capacity in heating of $22.6 \mathrm{~kW}$ (6.4 tons) were used to meet the maximum peak heating load of $249.1 \mathrm{~kW}$ ( 70.8 tons). The 15 GHPs were assumed to be all identical and connected in parallel to the GHEs (one GHP installed per building zone, see Section 2.1.2). It was also assumed that the entering water temperatures (EWTs), both on the source and load side (building), were the same for all GHPs at all times. Therefore, all the GHPs were assumed to have the same coefficient of performance (COP) and capacity (CAP) when operating. Figure 4 shows the COP and CAP curve fits of the selected GHP as a function of the EWT at a flow rate of $0.9 \mathrm{~L} / \mathrm{s}(14.2 \mathrm{gpm})$. These curves were estimated from the performance data sheets of the manufacturer.

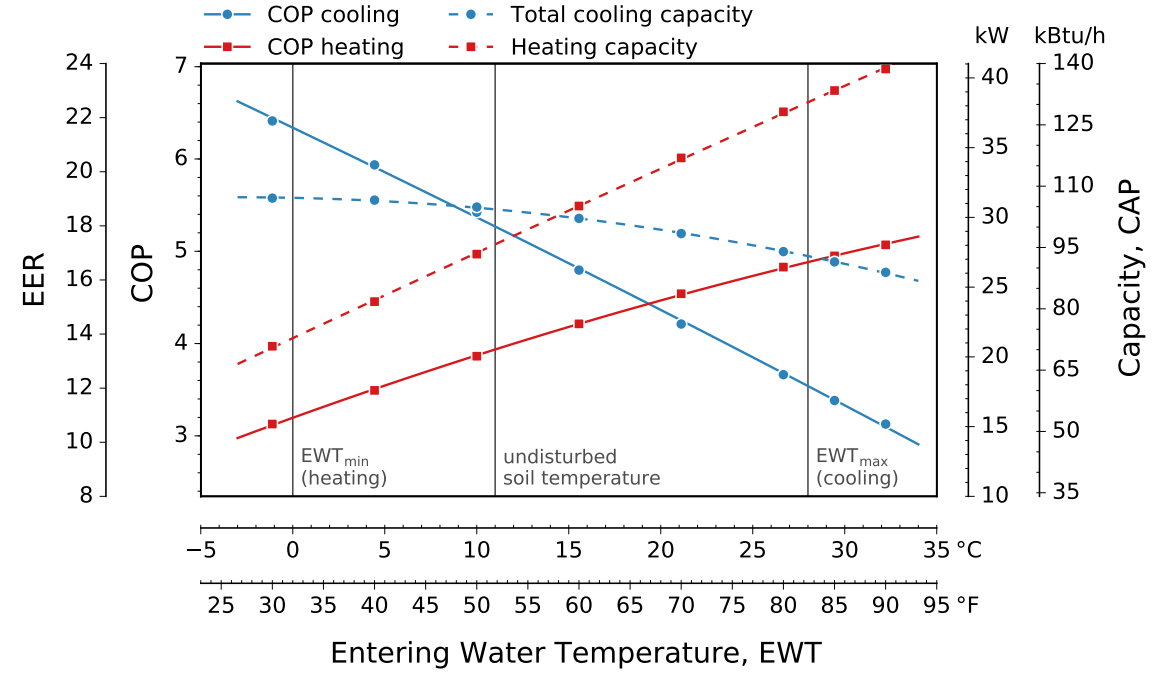

Figure 4: Curve fits of the coefficient of performance (COP) and total cooling and heating capacity (CAP) of the selected ground heat pump, estimated from the performance data sheets of the manufacturer, as a function of the entering water temperature at a flow rate of $0.9 \mathrm{~L} / \mathrm{s}(14.2 \mathrm{gpm})$.

Design and Undisturbed Subsurface Temperatures. The undisturbed subsurface temperature was set to a value of $11^{\circ} \mathrm{C}$ $\left(51.8^{\circ} \mathrm{F}\right)$, a value that is representative of locations in the 5B USA climate zone. For instance, the undisturbed ground temperature in the Denver area, Colorado, is about $11^{\circ} \mathrm{C}\left(52^{\circ} \mathrm{F}\right)$ according to McQuay International (2002).

Following ASHRAE (2011) guidelines, the minimum EWT in heating mode was set to $0^{\circ} \mathrm{C}\left(32^{\circ} \mathrm{F}\right), 11^{\circ} \mathrm{C}\left(51.8^{\circ} \mathrm{F}\right)$ below the undisturbed ground temperature. In cooling mode, the maximum EWT was set to $28^{\circ} \mathrm{C}\left(82.4^{\circ} \mathrm{F}\right), 17^{\circ} \mathrm{C}\left(62.6^{\circ} \mathrm{F}\right)$ above the undisturbed ground temperature.

Heat Carrier Fluid. According to CAN/CSA-C448 (2013), the heat-transfer fluid shall ensure freeze protection to at least $5{ }^{\circ} \mathrm{C}$ $\left(9^{\circ} \mathrm{F}\right)$ below the minimum loop design temperature. Compliance to this requirement was ensured by using a 25 wt $\%$ propylene glycol heat carrier solution, which is characterized by a freezing point of $-10.44{ }^{\circ} \mathrm{C}\left(13.20^{\circ} \mathrm{F}\right)$. A minimum concentration of $25 \mathrm{wt} \%$ is recommended to avoid problems of corrosion and bacteria. Table 1 presents the thermophysical properties of the selected heat carrier fluid at the minimum design EWT of $0{ }^{\circ} \mathrm{C}\left(32^{\circ} \mathrm{F}\right)$ in heating, as well as the minimum flow rate required in the U-pipe and coaxial configurations to ensure turbulent flow. Values for pure water are also provided for comparison.

\begin{tabular}{|c|c|c|c|}
\hline Fluid property $^{\dagger}$ & Units & Prop. Glycol & Pure Water \\
\hline Dynamic viscosity & $\mathrm{mPa} \cdot \mathrm{s}\left(\mathrm{lb}_{\mathrm{m}} / \mathrm{ft} \cdot \mathrm{h}\right)$ & $5.91(14.30)$ & $1.77 \quad(4.28)$ \\
\hline Density & $\mathrm{kg} / \mathrm{m}^{3}\left(\mathrm{lb}_{\mathrm{m}} / \mathrm{ft}^{3}\right)$ & $1030.92(64.36)$ & $999.84(62.42)$ \\
\hline \multicolumn{4}{|l|}{ Min. turbulent flow rate $e^{\ddagger}$ : } \\
\hline Single/Double U-pipe GHEs & L/s (gpm) & $0.35 \quad(5.58)$ & $0.11 \quad(1.72)$ \\
\hline Coaxial GHEs & $\mathrm{L} / \mathrm{s}(\mathrm{gpm})$ & $1.66(26.32)$ & $0.51 \quad(8.13)$ \\
\hline
\end{tabular}

Table 1: Heat carrier fluid (25 wt \% propylene glycol) and pure water properties at the design minimum EWT of $0{ }^{\circ} \mathrm{C}\left(32^{\circ} \mathrm{F}\right)$. The freezing point of $25 \mathrm{wt} \%$ propylene glycol is $-10.44{ }^{\circ} \mathrm{C}$ $\left(13.21^{\circ} \mathrm{F}\right)$.

\footnotetext{
Fluid properties were calculated with the GLHEPro software (Spitler et al., 2016).

Flow is assumed turbulent at $R e>2300$. See Figure 2 for dimensions of the U-pipe and coaxial GHEs.
} 
Loop Pump Design. Each and every U-pipe and coaxial loops were assumed to be connected in parallel (see Section 2.1.2) to the main header and to have the same volumetric flow rate. Similarly, the GHPs were assumed to be all connected in parallel to a one-pipe loop system and to be activated on and off synchronously since they operate under identical conditions.

The one-pipe loop system was assumed to be equipped with a large central pump with on-off control and variable speed drives ensuring a constant nominal flow rate at various head losses (due to fluid temperature variations). The large pump and motor efficiency were assumed constant with mean values of, respectively, 70 and $90 \%$ based on values used by Kavanaugh (2011). The central loop pump was assumed to be cycled off when the GHPs were not activated. A constant hydraulic pressure of $90 \mathrm{kPa}$ ( $30 \mathrm{ft}$ of water head) was maintained within the loop during these off times by a smaller central pump that operated in parallel at $25 \%$ of the design volumetric flow rate. The smaller central loop pump was assumed to be cycled off when the GHPs were activated. The smaller pump and motor efficiency were also considered to be constant with values of, respectively, 50 and $85 \%$ based on values used by Kavanaugh (2011). Note that the heat rejected to the ground by the pumps was not considered in the sizing calculation and hourly simulation of the GHEs since this component could not be directly accounted for in the GLHEPro software.

Design Volumetric Flow Rate. The total volumetric flow rate $\dot{V}$ was designed to ensure a ratio of $0.054 \mathrm{~L} / \mathrm{s} / \mathrm{kW}$ ( $3 \mathrm{gpm} / \mathrm{ton}$ ) of heating load during peak conditions. Considering that the maximum heating peak load is $249.1 \mathrm{~kW}(850.0 \mathrm{kBtu} / \mathrm{h})$, the design volumetric flow rate is estimated at $13.5 \mathrm{~L} / \mathrm{s}(214 \mathrm{gpm})$ for the entire system or $0.9 \mathrm{~L} / \mathrm{s}(14.2 \mathrm{gpm})$ per GHP.

For the coaxial configuration, the design volumetric flow rate had to be increased from this calculated value to ensure non-laminar flow $(R e>2300)$ on each and every loop of the GHE at the design EWT in heating mode. The design volumetric flow rate was calculated in this case by multiplying the minimum turbulent flow rate in heating mode of Table 1 by the number of coaxial boreholes determined during the sizing calculations.

\section{Energy Consumption Analysis}

Heat Pump Performance. The GHPs operating time in heating $\left(O T_{h}\right)$ and cooling mode $\left(O T_{c}\right)$ within a given 1-hour time interval $\tau$ was calculated using the curve fits of CAP (Figure 4) and the simulated EWT as:

$$
O T_{h}[\tau]=\frac{1}{N_{G H P}} \cdot \frac{Q_{h}[\tau]}{C A P_{h}(E W T[\tau])} \quad \text { and } \quad O T_{c}[\tau]=\frac{1}{N_{G H P}} \cdot \frac{Q_{c}[\tau]}{C A P_{c}(E W T[\tau])}
$$

where $N_{G H P}$ is the total number of ground heat pumps and $Q_{h}$ and $Q_{c}$ are the hourly building heating and cooling loads. The total electrical power $\left(W_{G H P}\right)$ consumed by the 15 GHPs over the 10-year simulation period was then calculated using the curve fits of $C O P$ and $C A P$ (Figure 4) and the $O T$ calculated with Equation 1:

$$
W_{G H P}=N_{G H P} \times \sum_{\tau=1}^{24 \times 365 \times 10}\left(\frac{C A P_{h}(E W T[\tau])}{C O P_{h}(E W T[\tau])} \cdot O T_{h}[\tau]+\frac{C A P_{c}(E W T[\tau])}{C O P_{c}(E W T[\tau])} \cdot O T_{c}[\tau]\right)
$$

Pumping Energy. The energy consumed by the ground loop pumps (GLPs) may account for a significant portion of the building annual energy consumption (Bernier, 2001). The electrical consumption of the large and smaller loop pumps $\left(W_{G L P}\right)$ over the 10-year simulation period was evaluated with the following equation:

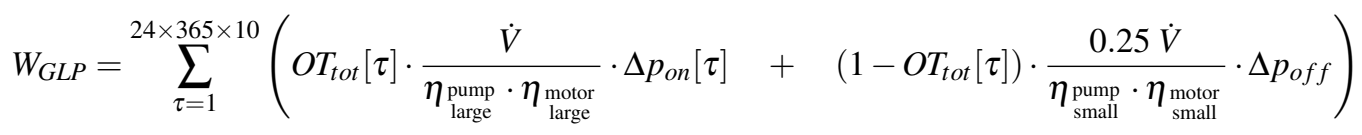

where $n_{\text {pump }}$ and $n_{\text {motor }}$ refer, respectively, to the pumping and motor efficiency of the large and small loop pumps, $\dot{V}$ is the design volumetric flow rate, $\Delta p_{\text {on }}$ is the time-varying pressure drop in the loop system while the GHPs are activated, $\Delta p_{\text {off }}$ is the constant pressure head of $90 \mathrm{kPa}$ ( $30 \mathrm{ft}$ of water head) delivered by the smaller loop pump when the GHPs are not activated and $O T_{\text {tot }}$ is the total period of time during which the GHPs are operated within a given 1-hour time interval $\tau$ and corresponds to the sum of $O T_{h}[\tau]$ and $O T_{c}[\tau]$.

Only the pressure drop in the borehole pipes and in the water coil of the GHPs were considered for the calculation of $\Delta p_{o n}$. The pressure drops in the return and supply header, valves and pipeline fittings were neglected. The water pressure drop (WPD) in the GHPs was determined with a curve fit of the performance data sheets of the selected GHP (ClimateMaster, 2016). For the single and double U-pipe configurations, $\Delta p_{\text {on }}$ was calculated as the sum of the WPD and the pressure drop in the descending 
and ascending legs of the U-pipe. For coaxial configurations, $\Delta p_{o n}$ was calculated as the sum of the WPD and the pressure drop in the annular duct and in the inner pipe conduit.

Assuming non-laminar flow conditions at all times $(R e>2300)$, the pressure drop for circular pipe flow was calculated at every time step $\tau$ with the equations presented in VDI-Gesellschaft (2010):

$$
\Delta p_{\text {pipe }}[\tau]=f_{\text {pipe }} \frac{L_{\text {pipe }}}{d_{i}} \frac{\rho[\tau] w_{\text {pipe }}^{2}}{2} \quad \text { where } \quad f_{\text {pipe }}=0.3164 \operatorname{Re}[\tau]^{-1 / 4}
$$

where $f_{\text {pipe }}, L_{\text {pipe }}$, and $d_{i}$ are, respectively, the friction factor, the length, and the inside diameter of the pipe, $w_{\text {pipe }}$ is the average velocity of the fluid in the pipe, $\rho$ is the fluid density, and $R e$ is the Reynolds number. The pressure drop for annular flow was calculated at every time step $\tau$ with the equations presented in Gnielinski (2009):

$$
\Delta p_{\text {ann }}[\tau]=f_{\text {ann }}[\tau] \frac{L_{a n n}}{d_{h}} \frac{\rho[\tau] w_{a n n}^{2}}{2} \quad \text { where } \quad f_{\text {ann }}[\tau]=\left(1.8 \log _{10}\left(\operatorname{Re}[\tau] \frac{\left(1+a^{2}\right) \ln a+\left(1-a^{2}\right)}{(1-a)^{2} \ln a}\right)-1.5\right)^{-2}
$$

where $f_{a n n}$ and $L_{a n n}$ are, respectively, the friction factor and length of the annulus, $w_{a n n}$ is the average velocity of the fluid in the annulus, $a$ is the ratio between the outer diameter of the inner tube and the inner diameter of the outer tube, and $d_{h}$ is the hydraulic diameter, which corresponds to the length between the inner diameter of the outer tube and the outer diameter of the inner tube. The Reynolds number $R e$ is calculated using the hydraulic diameter $d_{h}$. The fluid properties (density and dynamic viscosity) were estimated in Equations 4 and 5 for every time step $\tau$ by linear interpolation using property tables that were produced with the GLHEPro software.

\section{Cost Analysis}

To assess the economic performance of GHEs equipped with thermally enhanced pipes, a life-cycle cost analysis was performed, which consisted in calculating the construction cost of the GHE field and the net present value (NPV) of 10 years of operation of the GCHP system. The construction cost of the GHEs included the cost of drilling, installation labor, heat transfer fluid, grout, spacer clips and pipes. Table 2 presents the material and labor costs that were used to calculate the borehole construction cost for the various configurations considered in this study. The costs are given for a borehole of $152 \mathrm{~m}(500 \mathrm{ft})$ length. All other construction costs were assumed the same from one configuration to another and were excluded from the analysis. This included the cost of the heat and loop pumps, of the horizontal pipes and trenches, and of the geothermal vault.

The operation cost included the NPV of the electrical energy used by the heat and loop pumps over the 10-year simulation period (see Equations 2 and 3). All other sources of operation costs were excluded from this analysis. The NPV of 10 years of operation was evaluated by the following equation (Park, 2010):

$$
\text { Operation Cost Net Present Value }=\sum_{n=1}^{10} \frac{\left(W_{G P H}[n]+W_{G L P}[n]\right) \cdot E C \cdot\left(1+I_{E}\right)^{n}}{(1+i)^{n}}
$$

where $n$ is the year number, $I_{E}$ is the electricity escalation rate assumed to be $3 \%$ and $i$ is the constant discount rate assumed

\begin{tabular}{|c|c|c|c|c|c|c|}
\hline & \multicolumn{2}{|c|}{ Single U-pipe } & \multicolumn{2}{|c|}{ Double U-pipe } & \multicolumn{2}{|c|}{ Coaxial } \\
\hline & HDPE & $\mathrm{TE}$ & HDPE & $\mathrm{TE}$ & HDPE & $\overline{\mathrm{TE}}$ \\
\hline \multicolumn{7}{|l|}{ Material Costs (\$US) } \\
\hline Loop & 570 & 915 & 1240 & 1930 & 2000 & 3000 \\
\hline Heat carrier fluid & 24 & 24 & 47 & 47 & 89 & 89 \\
\hline Grout & 750 & 750 & 614 & 614 & 387 & 387 \\
\hline Spacer clips & 147 & 147 & 147 & 147 & 0 & 0 \\
\hline \multicolumn{7}{|l|}{ Labor Costs (\$US) } \\
\hline Installation & 650 & 650 & 650 & 650 & 1300 & 1300 \\
\hline Drilling & 8000 & 8000 & 8000 & 8000 & 8000 & 8000 \\
\hline Total borehole cost (\$US) & 10141 & 10486 & 10698 & 11388 & 11776 & 12776 \\
\hline
\end{tabular}
equal to $6 \%$ based on values used in Bernier (2006) and Hénault et al. (2016), EC is the average electricity cost in USA assumed equal to $10.60 \phi / \mathrm{kW} \cdot \mathrm{h}$ based on EIA (2016), and $n$ is the yearly index.

Table 2: Material and labor costs details in \$US calculated for a single borehole of $152 \mathrm{~m}(500 \mathrm{ft})$ for the three GHE configurations (single U-pipe, double Upipe, and coaxial) and two pipe materials (HDPE and TE) considered in this study 


\section{RESULTS}

Results for the sizing calculations, energy consumption, and cost analysis are presented for each GHE configuration in Table 3. Also, percentage reduction of the borehole thermal resistance and total GHE field length, area, and construction costs obtained when using TE pipes instead of HDPE pipes are presented in Table 4 for each configuration considered.

\begin{tabular}{|c|c|c|c|c|c|c|c|}
\hline & \multirow[b]{2}{*}{ Units } & \multicolumn{2}{|c|}{ Single U-pipe } & \multicolumn{2}{|c|}{ Double U-pipe } & \multicolumn{2}{|c|}{ Coaxial } \\
\hline & & HDPE & $\mathrm{TE}$ & HDPE & $\mathrm{TE}$ & HDPE & $\mathrm{TE}$ \\
\hline \multicolumn{8}{|l|}{ GHE Sizing Calculation } \\
\hline Design flow rate, $\dot{V}$ & $\begin{array}{l}\mathrm{L} / \mathrm{s} \\
\mathrm{gpm}\end{array}$ & $\begin{array}{r}13.5 \\
214\end{array}$ & $\begin{array}{r}13.5 \\
214\end{array}$ & $\begin{array}{r}13.5 \\
214\end{array}$ & $\begin{array}{r}13.5 \\
214\end{array}$ & $\begin{array}{r}18.7 \\
296\end{array}$ & $\begin{array}{r}15.3 \\
243\end{array}$ \\
\hline Borehole thermal resistance & $\begin{array}{l}\mathrm{m} \cdot \mathrm{K} / \mathrm{W} \\
\mathrm{h} \cdot \mathrm{ft} \cdot{ }^{\circ} \mathrm{F} / \mathrm{Btu}\end{array}$ & $\begin{array}{l}0.0865 \\
0.1497\end{array}$ & $\begin{array}{l}0.0672 \\
0.1163\end{array}$ & $\begin{array}{l}0.0488 \\
0.0845\end{array}$ & $\begin{array}{l}0.0372 \\
0.0644\end{array}$ & $\begin{array}{l}0.0926 \\
0.1603\end{array}$ & $\begin{array}{l}0.0700 \\
0.1212\end{array}$ \\
\hline Number of boreholes & - & 12 & 11 & 10 & 9 & 11 & 9 \\
\hline Borehole length & $\begin{array}{l}\mathrm{m} \\
\mathrm{ft}\end{array}$ & $\begin{array}{l}158 \\
518\end{array}$ & $\begin{array}{l}152 \\
499\end{array}$ & $\begin{array}{l}143 \\
469\end{array}$ & $\begin{array}{l}145 \\
476\end{array}$ & $\begin{array}{l}149 \\
489\end{array}$ & $\begin{array}{l}155 \\
509\end{array}$ \\
\hline GHE field length & $\begin{array}{l}\mathrm{m} \\
\mathrm{ft}\end{array}$ & $\begin{array}{l}1891 \\
6204\end{array}$ & $\begin{array}{l}1669 \\
5476\end{array}$ & $\begin{array}{l}1432 \\
4698\end{array}$ & $\begin{array}{l}1303 \\
4275\end{array}$ & $\begin{array}{l}1641 \\
5384\end{array}$ & $\begin{array}{l}1398 \\
4587\end{array}$ \\
\hline GHE field area & $\begin{array}{l}\mathrm{m}^{2} \\
\mathrm{ft}^{2}\end{array}$ & $\begin{array}{r}432 \\
4650\end{array}$ & $\begin{array}{r}396 \\
4263\end{array}$ & $\begin{array}{r}360 \\
3875\end{array}$ & $\begin{array}{r}324 \\
3488\end{array}$ & $\begin{array}{r}396 \\
4263\end{array}$ & $\begin{array}{r}324 \\
3488\end{array}$ \\
\hline \multicolumn{8}{|c|}{ Energy Analysis (Yearly Average) } \\
\hline Heat pump power, $W_{G H P}$ & $\begin{array}{l}\mathrm{kW} \cdot \mathrm{h} / \mathrm{yr} \\
\mathrm{kBtu} / \mathrm{yr}\end{array}$ & $\begin{array}{r}42648 \\
145521\end{array}$ & $\begin{array}{r}42712 \\
145739\end{array}$ & $\begin{array}{r}42832 \\
146149\end{array}$ & $\begin{array}{r}42910 \\
146415\end{array}$ & $\begin{array}{r}40999 \\
146719\end{array}$ & $\begin{array}{r}42150 \\
143822\end{array}$ \\
\hline Loop pumps power, $W_{G L P}$ & $\begin{array}{l}\mathrm{kW} \cdot \mathrm{h} / \mathrm{yr} \\
\mathrm{kBtu} / \mathrm{yr}\end{array}$ & $\begin{array}{r}8257 \\
28174\end{array}$ & $\begin{array}{r}8510 \\
29037\end{array}$ & $\begin{array}{r}6960 \\
23749\end{array}$ & $\begin{array}{r}7128 \\
24322\end{array}$ & $\begin{array}{r}9580 \\
32688\end{array}$ & $\begin{array}{r}7708 \\
26301\end{array}$ \\
\hline Total Operation Power & $\begin{array}{l}\mathrm{kW} \cdot \mathrm{h} / \mathrm{yr} \\
\mathrm{kBtu} / \mathrm{yr}\end{array}$ & $\begin{array}{r}50906 \\
173698\end{array}$ & $\begin{array}{r}51223 \\
174780\end{array}$ & $\begin{array}{r}49793 \\
169901\end{array}$ & $\begin{array}{r}50038 \\
170737\end{array}$ & $\begin{array}{r}50579 \\
172583\end{array}$ & $\begin{array}{r}49859 \\
170126\end{array}$ \\
\hline \multicolumn{8}{|l|}{ Cost Analysis } \\
\hline Real estate footprint ${ }^{\dagger}$ & $\$$ & 116250 & 106563 & 96875 & 87188 & 106563 & 87188 \\
\hline $\begin{array}{l}\text { Average operation cost } \\
10 \text { years operation cost NPV }\end{array}$ & $\begin{array}{l}\text { \$US/yr } \\
\text { \$US }\end{array}$ & $\begin{array}{r}5396 \\
46235\end{array}$ & $\begin{array}{r}5429 \\
46524\end{array}$ & $\begin{array}{r}5278 \\
45225\end{array}$ & $\begin{array}{r}5304 \\
45448\end{array}$ & $\begin{array}{r}5361 \\
45941\end{array}$ & $\begin{array}{r}5285 \\
45286\end{array}$ \\
\hline $\begin{array}{l}\text { Borehole construction cost } \\
\text { GHE field construction cost }\end{array}$ & $\begin{array}{l}\text { \$US/bore } \\
\text { \$US }\end{array}$ & $\begin{array}{r}10462 \\
125554\end{array}$ & $\begin{array}{r}10438 \\
114823\end{array}$ & $\begin{array}{r}10090 \\
100904\end{array}$ & $\begin{array}{l}10845 \\
97611\end{array}$ & $\begin{array}{r}11553 \\
127090\end{array}$ & $\begin{array}{r}12998 \\
116986\end{array}$ \\
\hline
\end{tabular}

Based on a land sale price of $269 \$$ per buildable square meter $(25 \$$ per buildable square foot).

\begin{tabular}{lccc}
\hline TE vs HDPE \% reduction for the: & Single U-pipe & Double U-pipe & Coaxial \\
\hline Borehole thermal resistance & 22.3 & 23.8 & 24.4 \\
Total GHE field length & 11.7 & 9.0 & 14.8 \\
Real estate footprint & 8.3 & 10.0 & 18.2 \\
Total GHE field construction cost & 8.6 & 3.3 & 8.0 \\
\hline
\end{tabular}

Table 4: For each GHE configuration, \% reduction of the borehole thermal resistance and total GHE field length, area, and construction costs obtained when using TE pipes instead of HDPE pipes.

\section{DISCUSSION}

Sizing calculation. Depending on the configuration, results in Table 4 show that the use of TE pipes instead of standard HDPE pipes allowed a reduction of the borehole thermal resistance between 22.3 and $24.4 \%$ and a reduction of the total GHE length between 9.0 and $14.8 \%$. As shown in Table 3, the double U-pipe configuration equipped with TE pipes has the smallest GHE 
design length, with a total borehole length that is $31.1 \%$ shorter compared to the single U-Pipe GHE equipped with standard HDPE pipes. This important reduction is not only due to the lower thermal resistance of the TE double U-pipe configuration, but also because of its greater heat storage capacity that helps to dampen the impact of peak loads on the required length of the GHE (Raymond et al., 2015). Similarly, coaxial GHEs have 3.8 times more heat storage capacity than the single U-pipe GHEs. This explains why the calculated length for the HDPE and TE coaxial GHEs are smaller than those for single U-pipe by, respectively, $13.2 \%$ and $16.2 \%$, even though the coaxial thermal resistance is higher in both cases.

Energy analysis. Results from the energy analysis show that the power consumption of the GHPs is very similar for all U-pipe GHEs, ranging from $42648 \mathrm{~kW} \cdot \mathrm{h} / \mathrm{yr}(145521 \mathrm{kBtu} / \mathrm{yr})$ for the HDPE single U-pipe to $42910 \mathrm{~kW} \cdot \mathrm{h} / \mathrm{yr}(146415 \mathrm{kBtu} / \mathrm{yr})$ for the TE double U-pipe. Assuming an electricity cost of $10.60 \notin / \mathrm{kW} \cdot \mathrm{h}$, this corresponds to a difference of less than $30 \$ / \mathrm{yr}$ for the operation cost of the GHPs. This shows that the use of TE pipes does not significantly affect the performance of the GHP when sizing calculations are done properly. The GHP energy consumption of the coaxial GCHP systems are the lowest due to the increased flow rate, which helps improving the performance of the GHPs. On the other hand, this is counterbalanced by a higher loop pumping power consumption that is mainly due to the increased pressure drop within the inner pipe of the coaxial GHEs. This could have been mitigated by the use of baffles, mounted within the annulus, to enforce turbulence at lower flow rates (Steins et al., 2012). It is also worth noting that the double U-pipe GHEs require about $16 \%$ less pumping energy than the single U-pipe GHEs. This is explained by the fact that, for an equal total flow rate of $13.5 \mathrm{~L} / \mathrm{s}(214 \mathrm{gpm})$, the mean velocity of the fluid in each loop connected in parallel to the main header is more than twice lower for the double U-Pipe than for the single U-Pipe. As per Equation 4, this results in a significant reduction of the pressure drop and a lower loop pumping power consumption when the large loop pump is operated. For the same reasons, the power consumption for pumping is slightly higher for all the GHEs equipped with TE pipes since the number of boreholes connected in parallel to the main header is less than those equipped with standard HDPE pipes.

Cost analysis. Results for the life-cycle analysis (Table 3) reveal that the 10 years of operation NPV are very similar for all the GHE configurations considered, ranging from 45225 \$ for the HDPE double U-pipe to 46524 \$ for the TE single U-pipe. The TE double U-pipe GHE have the lowest construction cost and appears to be the best option, both technically and financially, for the conditions represented in this work. In contrast, the coaxial GHEs have the greatest construction costs due to the higher trade and installation costs of the coaxial loops (see Table 2). Results in Table 4 show that TE pipes allowed a reduction of the construction costs between 3.3 and $8.6 \%$ when respectively compared to GHEs with same configuration and regular HDPE pipes. In all cases, these results suggest that GHEs equipped with TE pipes are an economically viable solution, despite the current typical trade cost of TE pipes being almost two times higher than standard HDPE pipes.

Furthermore, secondary benefits of using TE pipes to reduce the size of the GHE fields must also be factored in. As shown in Table 3, the reduction of the number of boreholes also allows to lower the total land area that is required to build the GHE fields. For larger geothermal project in urban areas where space is limited and where the land sale price per buildable square foot is high, a reduction in the number of boreholes by about $10 \%$ could represent significant additional savings on the initial cost of a project. Table 4 shows that in this study, the use of TE pipes instead of standard HDPE pipes allowed an additional saving of $8.3,10.0$ and $18.2 \%$ on the real estate value, respectively, for the single U-pipe, double U-pipe, and coaxial configuration. Moreover, less drilling length also means less fuel consumption during construction, smaller carbon footprint, shorter time of installation, less drilling residue, and less horizontal trench work. Besides, the trade cost of TE pipes can be expected to decrease in the future, which will increase even more the benefit of using TE pipes for the construction of GHEs. Of course, as with any cost analysis, the results presented here depends on the assumptions used. Benefit of using TE pipes may be greater or lower depending on drilling, material, and labor costs that can vary greatly from one location to the other in North America.

\section{CONCLUSION}

This study compared the performances of single U-pipe, double U-pipe, and coaxial ground heat exchangers (GHE) equipped with standard HDPE and thermally enhanced (TE) pipes. Sizing calculations and 10-year hourly simulations were carried out with the GLHEPro software using as input a synthetic thermal load profile of a reference, heating-dominated, medium office building located in the U.S. climate zone 5B enclosing Colorado. Energy consumption by the ground heat and ground loop pumps were then calculated from the simulated outputs and a life-cycle cost analysis was performed to compare the costs of construction and operation of the GHEs equipped with TE pipes with those equipped with standard HDPE pipes.

Results showed that the double U-pipe equipped with TE pipes was the best configuration for the conditions considered in this study. Depending on the configuration, the use of TE pipes instead of standard HDPE pipes allowed a reduction of the GHE 
length between 9.0 and $14.8 \%$ and a reduction of the construction cost between 3.3 and $8.6 \%$. For each configuration tested, the operation costs were similar between the GHEs equipped with HDPE and TE pipes. This study demonstrates that GHEs equipped with TE pipes can be a financially viable and environmentally beneficial solution, especially if secondary benefits are factored in such as saved footprints on available real estate, a shorter time and smaller cost of installation, smaller carbon footprints, and less drilling residue. Future work on this topic will include the development of a tool to quickly and easily carry out sizing, performance and cost comparison analyses for a wide range of situations to present a more precise and realistic insight into the pros and cons of using TE pipes in the construction of GHE.

\section{ACKNOWLEDGMENTS}

The authors would like to kindly acknowledge Professor Jeffrey Spitler at Oklahoma State University for providing a noncommercial license of GLHEPro for doing this study. This research was supported by the Mitacs Accelerate scholarship of Jean-Sébastien Gosselin and the NSERC-discovery grant of Professor Jasmin Raymond. We thank the anonymous reviewers for their very helpful comments on the paper. The synthetic building load profile was downloaded free of charge from the OpenEI database (en.openei.org).

\section{REFERENCES}

Allan, M.L., Kavanaugh, S.P., 1999. Thermal conductivity of cementitious grouts and impact on heat exchanger length design for ground source heat pumps. HVAC\&R Research 5, 85-96. doi:10.1080/10789669.1999.10391226.

ASHRAE, 2011. 2011 ASHRAE Handbook - HVAC Applications. Si edition ed., American Society of Heating, Refrigerating and AirConditioning Engineers, Atlanta, GA.

Bernier, M.A., 2001. Ground-coupled heat pump system simulation. ASHRAE Transactions 107, 12.

Bernier, M.A., 2006. Closed-loop ground-coupled heat pump systems. ASHRAE Journal , 12-19.

CAN/CSA-C448, 2013. Design and installation of earth energy systems. Canadian Standards Association, Mississauga, Ontario, Canada.

Claesson, J., Hellström, G., 2011. Multipole method to calculate borehole thermal resistances in a borehole heat exchanger. HVAC\&R Research 17, 895-911. doi:10.1080/10789669.2011.609927.

ClimateMaster, 2016. Submittal Data - Tranquility Compact Belt Drive (TC) Series. Technical Report LC517. ClimateMaster. Oklahoma City, OK, USA. URL: http://www. climatemaster.com.

Crawley, D.B., Pedersen, C.O., Lawrie, L.K., Winkelmann, F.C., 2000. EnergyPlus: Energy Simulation Program. ASHRAE Journal $42,49-56$.

EIA, 2016. Electric Power Annual 2014. Technical Report. U.S. Energy Information Administration (EIA). Washington, DC 20585, United States. URL: www.eia.gov.

Gnielinski, V., 2009. Heat transfer coefficients for turbulent flow in concentric annular ducts. Heat Transfer Engineering 30, $431-436$. doi:10.1080/01457630802528661.

Gupta, R.K., Kennel, E., Kim, K.J., 2009. Polymer Nanocomposites Handbook. CRC Press.

Hellström, G., 1991. Ground Heat Storage - Thermal Analyses of Duct Storage Systems. Ph.D. thesis. University of Lund. Department of mathematical physics, Lund, Sweden.

Hénault, B., Pasquier, P., Kummert, M., 2016. Financial optimization and design of hybrid ground-coupled heat pump systems. Applied Thermal Engineering 93, 72-82. doi:10.1016/j . applthermaleng. 2015.09.088.

Kavanaugh, S., 2011. Less pumping means cooler ground loops. ASHRAE Journal 53.

McQuay International, 2002. Geothermal Heat Pump - Design Manual. Technical Report Application Guide AG 31-008. Staunton, Virginia, USA.

Park, C.S., 2010. Contemporary Engineering Economics. 5 edition ed., Prentice Hall, Boston.

Raymond, J., Frenette, M., Léger, A., Magni, É., Therrien, R., 2011. Numerical modeling of thermally enhanced pipe performances in vertical ground heat exchangers. ASHRAE Transactions 117.

Raymond, J., Léger, A., 2011. Le dimensionnement de systèmes géothermiques avec tuyaux Geoperformx. GeoConneXion Magazine Winter-Spring 2011, 16-20.

Raymond, J., Mercier, S., Nguyen, L., 2015. Designing coaxial ground heat exchangers with a thermally enhanced outer pipe. Geothermal Energy 3, 1. 
Spitler, J.D., 2000. GLHEPRO - a design tool for commercial building ground loop heat exchangers, in: Proceedings of the fourth international heat pumps in cold climates conference, Aylmer, Quebec, Canada. pp. 17-18.

Spitler, J.D., Marshall, C., Manickam, A., Dharapuram, M., Delahoussaye, R.D., Yeung, K.W.D., Young, R., Bhargava, M., Mokashi, S., Yavuzturk, C., Haider, M., Xu, X., Cullin, J., Dickinson, B., Lee, E., Grundmann, R., 2016. Users' Guide for GLHEPro 5.0 for Windows. Technical Report. School of Mechanical and Aerospace Engineering. Oklahoma State University, Stillwater, Oklahoma, United States.

Steins, C., Al-Sibai, F., Kneer, R., 2012. Influence of large coaxial borehole heat exchangers (storage type borehole heat exchangers) on heat transfer and heat extraction, in: Geothermal Energy Congress 2012, Karlsruhe, Germany.

VDI-Gesellschaft, 2010. VDI Heat Atlas. VDI-Verlag GmbH, Dusseldorf, Germany, Berlin; London.

Versaprofiles, 2014. HDPE pipe with increased thermal conductivity for geothermal applications. Technical Report. Saint-Lazare-deBellechasse, Québec, Canada. URL: http://www . versaprofiles .com/. 